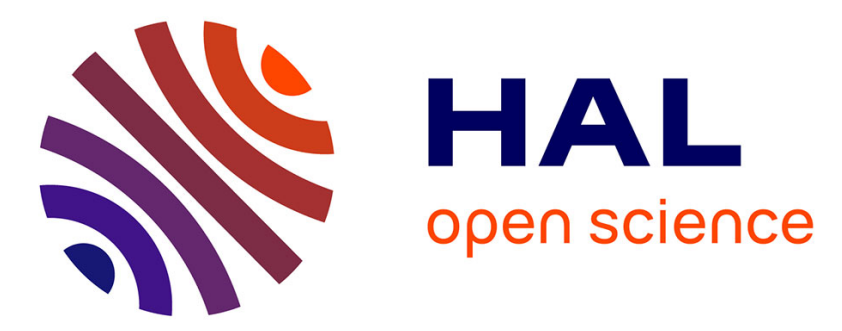

\title{
Validation of a new method using the reactivity of electrogenerated superoxide radical in the antioxidant capacity determination of flavonoids.
}

Carine Le Bourvellec, Didier Hauchard, André Darchen, Jean-Louis Burgot, Marie-Laurence Abasq

\section{To cite this version:}

Carine Le Bourvellec, Didier Hauchard, André Darchen, Jean-Louis Burgot, Marie-Laurence Abasq. Validation of a new method using the reactivity of electrogenerated superoxide radical in the antioxidant capacity determination of flavonoids.. Talanta, 2008, 75 (4), pp.1098-103. 10.1016/j.talanta.2008.01.007 . hal-00343754

\section{HAL Id: hal-00343754 https://hal.science/hal-00343754}

Submitted on 31 May 2020

HAL is a multi-disciplinary open access archive for the deposit and dissemination of scientific research documents, whether they are published or not. The documents may come from teaching and research institutions in France or abroad, or from public or private research centers.
L'archive ouverte pluridisciplinaire HAL, est destinée au dépôt et à la diffusion de documents scientifiques de niveau recherche, publiés ou non, émanant des établissements d'enseignement et de recherche français ou étrangers, des laboratoires publics ou privés. 


\title{
Validation of a new method using the reactivity of electrogenerated superoxide radical in the antioxidant capacity determination of flavonoids
}

\author{
Carine Le Bourvellec ${ }^{\mathrm{a}}$, Didier Hauchard ${ }^{\mathrm{b}}$, André Darchen ${ }^{\mathrm{c}}$, \\ Jean-Louis Burgot ${ }^{\mathrm{a}}$, Marie-Laurence Abasq ${ }^{\mathrm{a}, *}$ \\ a Laboratoire de Chimie Analytique URU-337, Faculté de Pharmacie, Université de Rennes 1, Avenue du Professeur \\ Léon Bernard, 35043 Rennes Cedex, France \\ ${ }^{\mathrm{b}}$ Equipe MaCSE, UMR CNRS 6226, Laboratoire Sciences Chimiques de Rennes, Ecole Nationale Supérieure de Chimie de Rennes, \\ Avenue du Général Leclerc, 35700 Rennes, France \\ c Equipe MI-CDR, UMR CNRS 6226, Laboratoire Sciences Chimiques de Rennes, Ecole Nationale Supérieure de Chimie de Rennes, Avenue du Général Leclerc, \\ 35700 Rennes, France
}

\begin{abstract}
This article lays out a new method to measure the antioxidant capacity of some flavonoids. The methodology developed is based on the kinetics of the reaction of the antioxidant substrate with the superoxide radical $\left(\mathrm{O}_{2}{ }^{\bullet-}\right)$. A cyclic voltammetric technique was used to generate $\mathrm{O}_{2}{ }^{\bullet-}$ by reduction of molecular oxygen in aprotic media. In the same experiment the consumption of the radical was directly measured by the anodic current decay of the superoxide radical oxidation in the presence of increasing concentrations of antioxidant substrate. The method was statistically validated on flavonoid monomers and on the standard antioxidants: trolox, ascorbic acid and phloroglucinol. The linear correlations between the anodic current of $\mathrm{O}_{2}{ }^{\bullet-}$ and the substrate concentration allowed the determination of antioxidant index values expressed by the substrate concentration needed to consume $30 \%\left(\mathrm{AI}_{30}\right)$ and $50 \%\left(\mathrm{AI}_{50}\right)$ of $\mathrm{O}_{2}{ }^{\bullet-}$ in given conditions of oxygen concentration and scanning rate. The fidelity of the method was examined intraday and interlaboratories.
\end{abstract}

Keywords: Antioxidant capacity; Cyclic voltammetry; Flavonoids; Superoxide radical

\section{Introduction}

Oxidative stress which arises in biologic systems leads to cellular death, contributes to faster aging and is responsible of pathology of many human diseases, like cancer, development of neurodegenerative or cardiac disorders [1]. It is associated with or leads to the generation of reactive oxygen species (ROS) including free radicals [2] which are strongly implicated in the pathophysiology of diseases [3,4]. In humans, defense system which protects against such oxidative damage includes endogenous enzymes like superoxide dismutase, glutathione peroxidase, catalase and non-enzymatic system as low molecular antioxidants and vitamins [5]. It is well known that many polyphenol compounds are brought by human nutrition and may

\footnotetext{
* Corresponding author. Tel.: +332232348 95; fax: +33223234912. E-mail address: marie-laurence.abasq@univ-rennes1.fr (M.-L. Abasq).
}

act as exogenous molecules taking part in the antioxidant defense system of the organism [6]. Their antioxidant capacity is defined as the capability of a compound to protect against oxidative degradation [7]. The mechanisms involved in the antioxidative actions of polyphenol compounds are described as scavenging capacity, metal chelating capacity, reducing capacity, enzyme inhibition and gene expression regulation [2].

Various methods have been developed to measure the in vitro antioxidant capacity of polyphenol compounds, phytochemicals and extracts although bioavailability, absorption, metabolism and pharmacokinetics must all be considered before attempting to extrapolate in vitro activity to the human in vivo situation. These methods are usually classified into two categories depending on the chemistry involved: (i) hydrogen atom transfer (HAT) methods which quantify a hydrogen atom capacity and (ii) electron transfer (ET) methods which measure an antioxidant reducing capacity. Details on the procedures and the chemistry of these methods are extensively reviewed in the literature [7-14]. 
Version définitive du manuscrit publiée dans / Final version of the manuscript published in :

Talanta (2008), Vol. 75, p. 1098-1103, DOI: 10.1016/j.talanta.2008.01.007

Journal homepage : www.elsevier.com/locate/talanta

Owing to the different reactions occurring in an antioxidant process, an antioxidant substrate may be fully characterized by complementary methods [7-14]. Consequently, as it has been pointed out, data of antioxidant capacities arising from different methods cannot be correlated, particularly when the chemistry involves different radical or oxidant sources. As a pertinent example, hydroxytyrosol which is a polyphenol from olive oil reacts with hydrogen peroxide but not with superoxide anion [15].

Among the radicals involved into the HAT and ET methods, peroxyl radicals $\mathrm{ROO}^{\bullet}, \mathrm{DPPH}^{\bullet}$ and $\mathrm{ABTS}^{\bullet+}$ are the most frequently used. The peroxyl radicals appear as interesting reactants because of their existence in vivo as ROS. Another ROS biologically relevant radical is the superoxide radical $\mathrm{O}_{2}{ }^{\bullet-}$ and some methods were developed to determine specifically the superoxide scavenging capacity. These assays are based on its generation by photochemistry of by using an enzymatic system and the inhibition reaction by the antioxidant substrate is usually measured by spectrophotometry, fluorescence or EPR techniques $[7,12,14,16]$. Electrochemical techniques for the generation of $\mathrm{O}_{2}{ }^{\bullet-}$ by reduction of dissolved oxygen in aprotic solvents is also a convenient method since no by-product are generated. $\mathrm{O}_{2}{ }^{\bullet-}$ is a long-lived species in aprotic media and the procedure is easy to carry out $[17,18]$. Moreover, cyclic voltammetry is adequate to follow reaction of electrogenerated $\mathrm{O}_{2}{ }^{\bullet-}$ with substrate. This was already described for some sulfur amino acids [19], esters [20], antioxidative agent [21] and drugs [22-24] but no protocol was really developed and statistically validated. Moreover, to our knowledge the interaction with polyphenol compounds following this methodology has not been reported yet. Electrochemistry approaches are also of special advantage in evaluation of antioxidant properties regarding the reducing capacity of a substrate by measuring the oxidation potential of the substrates, the studies on this subject has been reviewed recently [25].

In this work we report the procedure and the validation of an electroanalytical method of the in vitro antioxidant capacity determination of polyphenol compounds in a polar aprotic media. The methodology is based on the kinetic study by cyclic voltammetry of the interaction of the antioxidant substrate with superoxide anion radical $\mathrm{O}_{2}{ }^{\bullet-}$. The validation of the method was statistically performed on some flavonoid compounds (Fig. 1) and the standard antioxidants trolox, ascorbic acid and phloroglucinol.

\section{Experimental}

\subsection{Reagents}

Commercially available chemicals were used without any further purification. The $N, N$-dimethylformamide extra dry $\left(\left[\mathrm{H}_{2} \mathrm{O}\right] \leq 0.005 \%\right.$, stored over molecular sieve $\left.3 \AA\right)$ and the tetrabutylammonium hexafluorophosphate $\mathrm{Bu}_{4} \mathrm{NPF}_{6}$ of electrochemical grade were purchased from Fluka Chemie. Flavonoid monomers: (-)-epicatechin was purchased from Aldrich, phlorizin dihydrate from Fluka, quercetin dihydrate and rutin were purchased from Sigma Chemical<smiles>O=c1c(O)c(-c2ccc(O)c(O)c2)oc2cc(O)cc(O)c12</smiles>

Quercetin<smiles>Oc1cc(O)c2c(c1)O[C@H](c1ccc(O)c(O)c1)[C@H](O)C2</smiles>

(-)-Epicatechin<smiles>O=c1c(O[GeH2])c(-c2ccc(O)c(O)c2)oc2cc(O)cc(O)c12</smiles>

Rutin

(O-Glc-Rha : O-Rhamnoglucoside)<smiles>COc1cc(O)cc(O)c1C(=O)CCc1ccc(O)cc1</smiles>

(O-Glc : O-Glucoside)

Fig. 1. Chemical structure of the flavonoids investigated. 
Version définitive du manuscrit publiée dans / Final version of the manuscript published in :

Talanta (2008), Vol. 75, p. 1098-1103, DOI: 10.1016/j.talanta.2008.01.007

Journal homepage : www.elsevier.com/locate/talanta

Co. Standard antioxidants: ascorbic acid and trolox $(( \pm)-$ 6-hydroxy-2,5,7,8-tetramethylchroman-2-carboxylic acid) were purchased from Acros Organics, phloroglucinol dihydrate $\left(1,3,5\right.$-trihydroxybenzene $\left.\cdot 2 \mathrm{H}_{2} \mathrm{O}\right)$ was purchased from Aldrich.

\subsection{Equipment}

Cyclic voltammetry experiments were performed on a dual potentio-galvanostat PGSTAT100 in laboratory 1 or a PGSTAT30 in laboratory 2 (Autolab instrument, Eco Chemie B.V., Utrecht, The Netherlands). All measurements were carried out on a three-electrode thermostated cell. A glassy carbon disk working electrode (diameter $2 \mathrm{~mm}$ ), a platinum wire counter electrode and a reference electrode, $\mathrm{Ag} / \mathrm{AgCl}$ in $\mathrm{EtOH}$ saturated by $\mathrm{LiCl}$, were used for all electrochemical experiments. The reference electrode was separated from the solution by a salt bridge containing $0.5 \mathrm{M} \mathrm{Bu}_{4} \mathrm{NPF}_{6}$ in DMF. The glassy carbon disk working electrode was polished using silicon carbide 4000 paper with a LaboPol-5 (Struers, Ballerup, Denmark), washed with distilled water and then dried. For all measurements, the temperature was maintained at $20 \pm 0.02{ }^{\circ} \mathrm{C}$ with a Julabo heating circulator MP-5 (Julabo, Seelbach, Germany).

\subsection{Method}

\subsubsection{Cyclic voltammetry of oxygen}

$10 \mathrm{~mL}$ of an extra-dry DMF solution containing the supporting electrolyte $0.1 \mathrm{M} \mathrm{Bu}_{4} \mathrm{NPF}_{6}$ was saturated by dry air during $10 \mathrm{~min}$. In these conditions the solubility of oxygen was assumed to be $0.94 \times 10^{-3} \mathrm{M}$, this value corresponding to a partial pressure of 0.2 bar [26]. The cyclic voltammogramm (CV) of the oxygen reduction was then recorded at a scan rate $0.1 \mathrm{~V} \mathrm{~s}^{-1}$. The initial potential was fixed at $0 \mathrm{~V} v s . \mathrm{Ag} / \mathrm{AgCl}$. The scanning potential was reversed at $-0.9 \mathrm{~V} v s$. $\mathrm{Ag} / \mathrm{AgCl}$.

\subsubsection{Cyclic voltammetry of oxygen in the presence of antioxidant substrate}

A stock solution of the flavonoid monomer or the standard antioxidant was prepared at about $2.5 \times 10^{-2} \mathrm{M}$. Aliquots of the stock solution were successively added to the $10 \mathrm{~mL}$ oxygen solution in order to get an antioxidant substrate concentration in the range $(0-2.50 \mathrm{mM})$. After each aliquot addition, $\mathrm{CV}$ of the oxygen solution was recorded at a scan rate $0.1 \mathrm{~V} \mathrm{~s}^{-1}$.

\subsubsection{Statistical evaluation of the method}

The statistical analysis of the results was performed according to the well-recognized analytical parameters established by the official compendiums, scientific literature and Pharmacopeias. Analysis of variance and linear correlations tests were performed using the AVA V3-1 qualilab software package. A maximum risk of $5 \%$ of the measures outside the acceptance limits was considered statistically significant. Two independent laboratories, two equipments and two operators were involved in the statistical evaluation of the method.

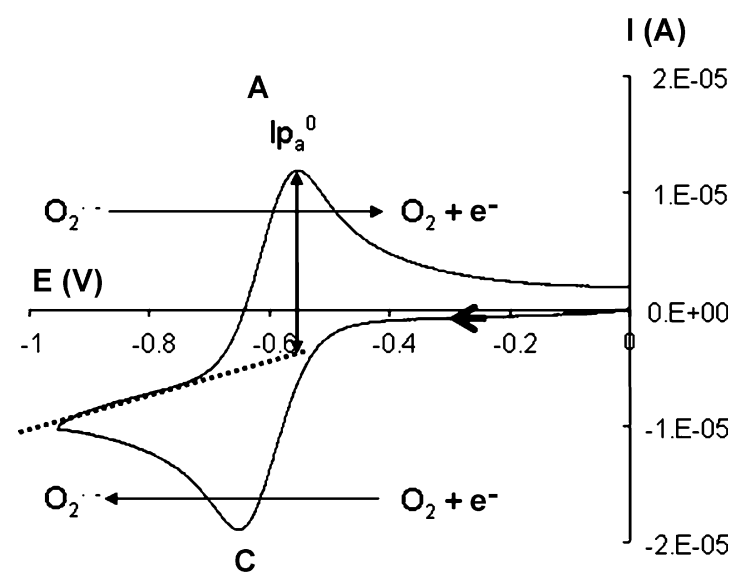

Fig. 2. Cyclic voltammogram of oxygen at a steady glassy carbon disk electrode in $\mathrm{DMF} / 0.1 \mathrm{M} \mathrm{Bu}_{4} \mathrm{NPF}_{6}$. Scan rate $0.1 \mathrm{~V} \mathrm{~s}^{-1}$.

\section{Results and discussion}

\subsection{Electrogeneration of superoxide radical}

Cyclic voltammetry technique [27] is used to generate the superoxide radical $\mathrm{O}_{2}{ }^{-}-$in the diffusion layer of a glassy carbon electrode by the one-electron reduction of molecular oxygen in DMF media (Fig. 2; peak C). The presence of the radical $\mathrm{O}_{2}{ }^{\bullet-}$ is easily detected by its anodic oxidation current measured at the same electrode during the reverse scan (Fig. 2; peak A). The reduction of $\mathrm{O}_{2}$ is a reversible reaction and it is known that $\mathrm{O}_{2}{ }^{\bullet-}$ radical is stable in aprotic media and dismutation does not occur during the time scale of the cyclic voltammetry in DMF solution $[17,18]$. Consequently, it is a convenient way to generate $\mathrm{O}_{2}{ }^{\bullet-}$ without enzyme systems and to study its reaction with a molecule or an extract provided the substrate is not active in the potential range of the reduction of oxygen. Interferences restrictions have been related in the article of Arnao concerning the radicals $\mathrm{DPPH}^{\bullet}$ and $\mathrm{ABTS}^{\bullet+}$ and the spectrophotometric detection [28]. In voltammetric detection, the substrate has not to be active in the potential range of the couple molecular oxygen/superoxide anion in order to avoid interference or a complex interpretation of the data. Fortunately, this was observed in this study despite the phenols are reducing agents. Indeed, the investigated substrates were oxidized at positive potentials.

In the development of the procedure, the CV was firstly recorded in the absence of the substrate to determine the current value $I_{\mathrm{p}_{\mathrm{a}}^{\mathrm{o}}}^{\mathrm{o}}$ as the anodic peak current of $\mathrm{O}_{2}{ }^{\bullet-}$ oxidation (Fig. 2). $I_{\mathrm{pa}}^{\mathrm{o}}$ is directly related to the $\mathrm{O}_{2}{ }^{\bullet-}$ concentration at the electrode surface and depends on the solubility of oxygen in DMF and the experimental parameters chosen to record the $\mathrm{CV}$.

Clearly it is important that the $I_{\mathrm{p}_{\mathrm{a}}^{\mathrm{O}}}^{\mathrm{o}}$ value is determined in identical conditions for each experiment. It means that the time scale of the $\mathrm{CV}$ and the electrode surface have to be the same. The time scale was controlled by the scan rate $0.1 \mathrm{~V} \mathrm{~s}^{-1}$ and the potential range was from 0 to $-0.9 \mathrm{~V} v s$. $\mathrm{Ag} / \mathrm{AgCl}$. The precision was determined on the $I_{\mathrm{p}_{\mathrm{a}}}^{\mathrm{O}}$ value over a period of 3 months and gave a relative standard deviation of $2.14 \%$ for interdays values $\left(\mathrm{RSD}_{r}\right)$ and of $2.21 \%$ for interlaboratories values $\left(\operatorname{RSD}_{R}\right)(n=18)$. These 


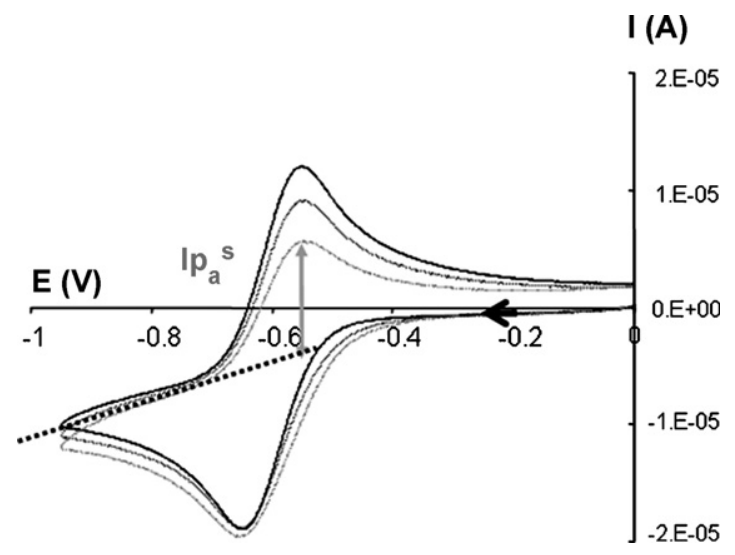

Fig. 3. Cyclic voltammograms of $\mathrm{O}_{2}$ reduction in the presence of increasing concentrations of phloroglucinol at a steady glassy carbon disk electrode in $\mathrm{DMF} / 0.1 \mathrm{M} \mathrm{Bu}_{4} \mathrm{NPF}_{6}$. Scan rate $0.1 \mathrm{~V} \mathrm{~s}^{-1}$. Phloroglucinol concentrations: ) $0 \mathrm{mM}$; $0.49 \mathrm{mM}$; $($ ) $1.64 \mathrm{mM}$.

results show a good precision on the $I_{\mathrm{p}_{\mathrm{a}}}^{\mathrm{o}}$ value and consequently on the solubility of atmospheric oxygen in DMF which was a key point in the validation of the method.

\subsection{Electrochemical behavior of oxygen in the presence of an antioxidant substrate}

The $\mathrm{CV}$ of the $\mathrm{O}_{2}$ reduction was recorded in the presence of a flavonoid monomer or a standard antioxidant with a view to evaluating the antioxidant capacity of the molecule looking at its reactivity toward $\mathrm{O}_{2}{ }^{\bullet-}$. The increase of the antioxidant substrate concentration leads to a decrease of $\mathrm{O}_{2}{ }^{\bullet-}$ anodic peak current $\left(I_{\mathrm{p}_{\mathrm{a}}}^{\mathrm{S}}\right)$ while the intensity of $\mathrm{O}_{2}$ cathodic current is not significantly modified as shown in Fig. 3 in the case of phloroglucinol. The decrease of the anodic peak current of $\mathrm{O}_{2}{ }^{\bullet-}$ suggests that the polyphenol substrate reacts irreversibly with $\mathrm{O}_{2}{ }^{\bullet-}$. For each antioxidant compound, a series of $I_{\mathrm{p}_{\mathrm{a}}}^{\mathrm{S}}$ values is determined from the $\mathrm{CVs}$ recorded for increasing antioxidant concentrations (Fig. 3). All antioxidant substrates exhibited a similar effect upon the $\mathrm{O}_{2}$ reduction.

At higher concentrations of some antioxidant substrates, a not-well defined reduction peak was observed at a potential more positive than the oxygen reduction peak. We could not attribute this peak to the reduction of an acidic hydrogen since the working electrode was vitreous carbon and not platinum [19]. The concentration range where we observed a significant additional peak was not within the linear range used in the determination of the antioxidant capacity values (Section 3.3.2).

The electrochemical behavior of oxygen may be summarized by the following Eqs. (1)-(3) where AH represents a flavonoid compound or a standard antioxidant. After the reversible reduction of oxygen (1) the electrogenerated superoxide anion reacts with AH (2) leading to products which are not electroactive in the scanned potential range. For this reaction we can follow the hypothesis of an $\mathrm{H}$ atom transfer (3) leading to radical $\mathrm{A}^{\bullet}$, which may be a phenoxy radical, and to the conjugated base of hydrogen peroxide [29-31].

Literature reports that some proton donating substrates $[17,22,32,33]$ increase the cathodic current of oxygen from a

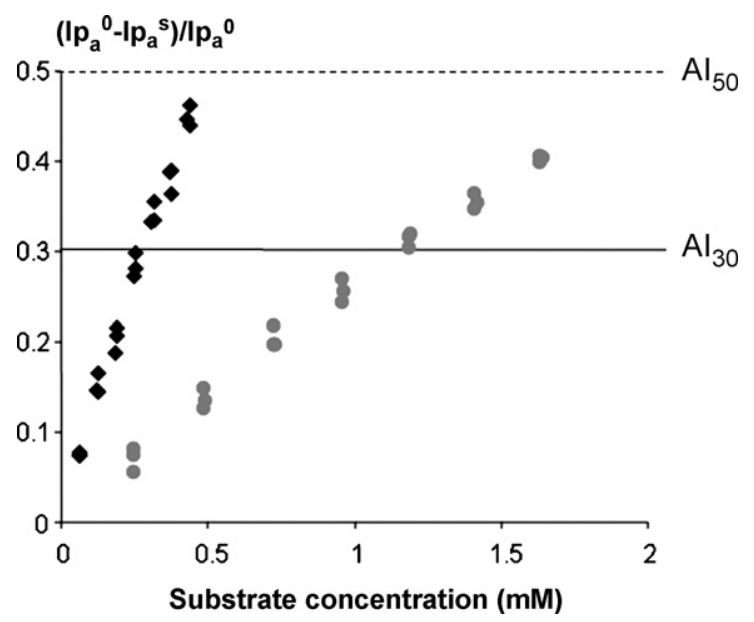

Fig. 4. Dimensionless parameter related to the decrease of superoxide anodic current $v s$. the substrate concentration in the linear range (data reported for analysis over 3 days) (( ) trolox; $(\diamond)$ quercetin).

one-electron to a two-electron reduction. The mechanism may be described by a first proton transfer (4) followed by electron transfer (5). With a second proton transfer (6) the overall reaction is a two-electron reduction of oxygen (7). In our experimental conditions we did not observe with flavonoid substrates the increase of oxygen current reduction which is expected in the hypothesis of a proton donating mechanism. Moreover, during the reverse scan until $0.6 \mathrm{~V} v s$. $\mathrm{Ag} / \mathrm{AgCl}$ we never observed an anodic peak which could be attributed to the oxidation of a phenoxide $\left(\mathrm{A}^{-}\right)$ arising from the proton transfer (4). So our observations suggest that the flavonoid compounds reacted with superoxide radical as $\mathrm{H}$ atom donors, as already reported with other methods [29-31].

$\mathrm{O}_{2}+\mathrm{e}^{-} \leftrightarrows \mathrm{O}_{2}^{\bullet-}$

$\mathrm{O}_{2}^{\bullet-}+\mathrm{AH} \rightarrow$ electroinactive compounds

$\mathrm{O}_{2}^{\bullet-}+\mathrm{AH} \rightarrow \mathrm{O}_{2} \mathrm{H}^{-}+\mathrm{A}^{\bullet}$

$\mathrm{O}_{2}^{\bullet-}+\mathrm{AH} \rightarrow \mathrm{HO}_{2}^{\bullet}+\mathrm{A}^{-}$

$\mathrm{HO}_{2}^{\bullet}+\mathrm{O}_{2}^{\bullet-} \rightarrow \mathrm{HO}_{2}^{-}+\mathrm{O}_{2}$

$\mathrm{HO}_{2}^{-}+\mathrm{AH} \rightarrow \mathrm{H}_{2} \mathrm{O}_{2}+\mathrm{A}^{-}$

$\mathrm{O}_{2}+2 \mathrm{e}^{-}+2 \mathrm{AH} \rightarrow \mathrm{H}_{2} \mathrm{O}_{2}+2 \mathrm{~A}^{-}$

\subsection{Development and statistical evaluation of the method}

The $I_{\mathrm{p}_{\mathrm{a}}}^{\mathrm{o}}$ and $I_{\mathrm{p}_{\mathrm{a}}}^{\mathrm{S}}$ values were determined as described above. The consumption of $\mathrm{O}_{2}{ }^{\bullet-}$ was expressed by a dimensionless parameter $\left(I_{\mathrm{p}_{\mathrm{a}}^{\mathrm{O}}}^{\mathrm{O}}-I_{\mathrm{p}_{\mathrm{a}}}^{\mathrm{S}}\right) / I_{\mathrm{p}_{\mathrm{a}}}^{\mathrm{O}}$ which was plotted $v s$. the substrate concentration (Fig. 4). When the antioxidant concentration increased, the calculated values for $\left(I_{\mathrm{p}_{\mathrm{a}}}^{\mathrm{o}}-I_{\mathrm{p}_{\mathrm{a}}}^{\mathrm{S}}\right) / I_{\mathrm{p}_{\mathrm{a}}}^{\mathrm{o}}$, were out of the straight line. These points were not represented in Fig. 4.

\subsubsection{Linearity}

The linearity of response was studied statistically for each molecule to establish an antioxidant capacity value in the adequate linear range (Table 1). The statistical analysis was performed using the ANOVA regression analysis option of the AVA 
Version définitive du manuscrit publiée dans / Final version of the manuscript published in :

Talanta (2008), Vol. 75, p. 1098-1103, DOI: 10.1016/j.talanta.2008.01.007

Journal homepage : www.elsevier.com/locate/talanta

Table 1

Characteristic parameters for the regression equation for standard antioxidants and flavonoids monomers

\begin{tabular}{lllll}
\hline Compounds & Linear range $(\mathrm{mM})$ & Slope & $y$-Intercept & $r^{2}$ \\
\hline Standard antioxidants & & & & \\
$\quad$ Trolox & $0.25-1.63$ & 0.239 & 0.020 & 0.995 \\
$\quad$ Phloroglucinol & $0.25-1.22$ & 0.262 & 0.037 & 0.995 \\
Ascorbic acid & $0.10-0.75$ & 0.740 & 0.031 & 0.987 \\
Flavonoid monomers & & & & \\
$\quad$ Phlorizin & $0.25-1.65$ & 0.275 & 0.026 & 0.993 \\
Rutin & $0.20-0.90$ & 0.405 & 0.024 & 0.991 \\
Epicatechin & $0.10-0.50$ & 0.761 & 0.034 & 0.994 \\
Quercetin & $0.05-0.45$ & 0.976 & 0.025 & 0.994 \\
\hline
\end{tabular}

V3-1 program. A value of $p<0.05$ was considered statistically significant.

Data for linearity of $\left(I_{\mathrm{p}_{\mathrm{a}}}^{\mathrm{o}}-I_{\mathrm{p}_{\mathrm{a}}}^{\mathrm{S}}\right) / I_{\mathrm{p}_{\mathrm{a}}}^{\mathrm{o}} v$. the substrate concentration were determined three times (one time a day) (Table 1). A linear correlation was found for each substrate in a given concentration range which is dependent on the reactivity of the substrate toward superoxide. Correlation coefficients, intercepts, slopes and linear range for the calibration data are given in Table 1 from a minimum of five-point linear plot with three replicates. All statistical tests performed by AVA V3-1 were validated except for the intercept test. The key point in this study was to demonstrate a linear interval in the current decay allowing the determination of antioxidant capacity values.

\subsubsection{Antioxidant capacity}

Under the same experimental conditions, the kinetics of the reaction between the antioxidant substrate and superoxide radical anion may be expressed by the slopes of straight lines (Fig. 4). These slope values are gathered in Table 1. For example, the standard trolox is four times less reactive than the flavon-3-ol quercetin. Instead of these slopes we preferred characterize the reactivity of antioxidant substrates by an antioxidant index AI. By analogy with the inhibiting concentration of antioxidant (IC),

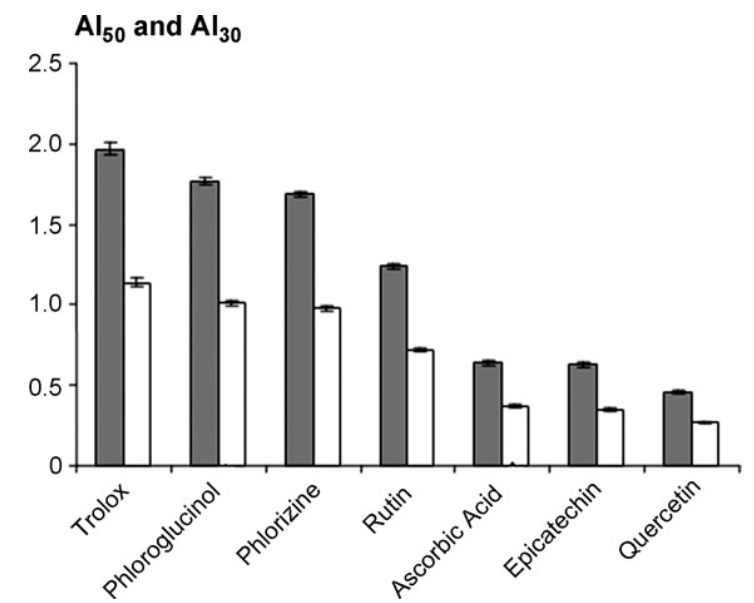

Fig. 5. Histogram of $\mathrm{AI}_{50}$ and $\mathrm{AI}_{30}$ values $(n=9)$. ( $\left.\square\right)$ : $\mathrm{AI}_{50}(\mathrm{mM})$; $(\square)$ : $\mathrm{AI}_{30}$ $(\mathrm{mM}) ;(工)$ : standard deviation of interday values.

we determined two indexes $\mathrm{AI}_{30}$ and $\mathrm{AI}_{50}$ by the concentration in $\mathrm{mM}$ of antioxidant substrate needed to consume superoxide radical as revealed by a current decrease, respectively $30 \%$ and $50 \%$ of the initial anodic current $I_{\mathrm{pa}_{\mathrm{a}}}^{\mathrm{O}}\left(\mathrm{Al}=\left(I_{\mathrm{Pa}^{\mathrm{a}}}^{\mathrm{O}}-I_{\mathrm{pa}_{\mathrm{a}}}^{\mathrm{S}}\right) / I_{\mathrm{p}_{\mathrm{a}}}^{\mathrm{O}}=\right.$ 0.3 or 0.5 ) (Fig. 4).

Fig. 4 shows that $\mathrm{AI}_{30}$ is within the linear interval response whether the $\mathrm{AI}_{50}$ value is an extrapolated value. With this antioxidant characterization, more the AI values are low, more the substrate has an antioxidant capacity toward superoxide.

\subsubsection{Precision on the $A I_{30}$ and $A I_{50}$ values}

Data are listed in Table 2 and are expressed as mean and confidence interval of $\mathrm{AI}_{30}$ and $\mathrm{AI}_{50}$ values. The precision on the $\mathrm{AI}_{30}$ and $\mathrm{AI}_{50}$ values calculated as relative standard deviation (RSD\%) was obtained in two levels: interdays $\mathrm{RSD}_{r}$ (three analysis for three days) and interlaboratories $\mathrm{RSD}_{R}$ (two laboratories, two equipments, two operators, three days, three analysis a day, the third day values were determined in lab2) (Table 2). All linear correlations used for the determination of the antiox-

Table 2

Precision data concerning the $\mathrm{AI}_{50}$ and $\mathrm{AI}_{30}$ values

\begin{tabular}{|c|c|c|c|c|c|}
\hline Compounds & & $\mathrm{AI}(\mathrm{mM})(n=9)$ & Confidence interval $(\mathrm{mM})$ & Interday $\mathrm{RSD}_{r}(\%)$ & Interlaboratory $\mathrm{RSD}_{R}(\%)$ \\
\hline \multirow[t]{2}{*}{ Trolox } & AI50 & 1.97 & {$[1.92-2.02]$} & 3.4 & 3.3 \\
\hline & $\mathrm{AI} 30$ & 1.14 & [1.10-1.17] & 4.8 & 4.2 \\
\hline Phloroglucinol & $\mathrm{AC} 30$ & 1.01 & [0.98-1.05] & 2.9 & 4.7 \\
\hline \multirow[t]{2}{*}{ Ascorbic acid } & AI50 & 0.64 & {$[0.60-0.68]$} & 5.9 & 7.4 \\
\hline & $\mathrm{AI} 30$ & 0.37 & {$[0.35-0.39]$} & 7.2 & 8.5 \\
\hline \multirow[t]{2}{*}{ Phlorizin } & AI50 & 1.69 & {$[1.66-1.71]$} & 1.8 & 1.9 \\
\hline & $\mathrm{AI} 30$ & 0.98 & {$[0.95-1.01]$} & 3.3 & 3.6 \\
\hline \multirow[t]{2}{*}{ Rutin } & AI50 & 1.24 & [1.20-1.29] & 3.2 & 5.0 \\
\hline & AI30 & 0.72 & {$[0.69-0.74]$} & 3.4 & 5.5 \\
\hline \multirow[t]{2}{*}{ Epicatechin } & AI50 & 0.63 & {$[0.61-0.65]$} & 4.4 & 4.9 \\
\hline & AI30 & 0.35 & {$[0.33-0.36]$} & 4.6 & 5.8 \\
\hline
\end{tabular}


Version définitive du manuscrit publiée dans / Final version of the manuscript published in :

Talanta (2008), Vol. 75, p. 1098-1103, DOI: 10.1016/j.talanta.2008.01.007

Journal homepage : www.elsevier.com/locate/talanta

idant values were obtained from independent stock solutions of the antioxidant substrate. The relative standard deviations were $<5 \%$ for the $\mathrm{AI}_{50}$ values except for the ascorbic acid substrate whether the $\mathrm{AI}_{30}$ values showed higher relative standard deviations.

\subsubsection{Comparison in the antioxidant capacity of the different substrates}

Histogram of Fig. 5 shows the decrease of the antioxidant capacity of the substrates from quercetin to trolox. Our results follow the same order of antioxidant capacity values given in the literature with independent methods for these molecules [34-38]. There is a general agreement that in flavonoid monomers the structural features that favors the radical scavenging activity is (i) the degree of hydroxylation (the ortho-diphenolic structure in the $\mathrm{B}$ ring and the $3-\mathrm{OH}$ group on the $\mathrm{C}$ ring) and (ii) the 2,3-double bond in conjugation with a 4-oxo function in the $\mathrm{C}$ ring. These criteria are related to the stabilization by conjugation of the phenoxy intermediate obtained after the $\mathrm{H}$-abstraction scavenging reaction [34-38]. In the flavonoid series, the flavon-3-ol quercetin, which is the most active $\left(\mathrm{AI}_{50}=0.46 \mathrm{mM}\right)$, fulfils all the conditions whether the dihydrochalcone phlorizin $\left(\mathrm{AI}_{50}=1.69 \mathrm{mM}\right)$ does not have these structural characteristics.

Ascorbic acid, a well-known antioxidant, exhibits the same antioxidant capacity than the flavan-3-ol epicatechin. The other standard antioxidants, trolox and phloroglucinol, are the less active substrates which we studied.

\section{Conclusion}

The electrochemical method described developed in this study allows the determination of an in vitro antioxidant capacity value of some flavonoid monomers and standard molecules.

The cyclic voltammetry technique is well-appropriated for the measurement of the antioxidant capacity of phenol substrate toward superoxide radical. Indeed the generation of the radical and the measurement of its consumption are conducted at the same electrode. An important requirement of the method is that the antioxidant substrate is not electroactive in the same potential range where the oxygen reduction occurs.

Superoxide is electrogenerated by the one-electron reduction of dioxygen and therefore its generation involves neither enzymes nor chelating metals as it is usually used in the methods testing the superoxide scavenging capacity. Consequently this method measures specifically the radical scavenging effect toward superoxide whether the other methods cannot discriminate possible synergic actions of the antioxidant activity of polyphenols [38].

\section{Acknowledgements}

This study received financial support from "Conseil Régional de Bretagne" and "CRITT Santé Bretagne" to whom the authors are grateful.

\section{References}

[1] J.L. Mark, Science 238 (1987) 1352-1353.

[2] B. Halliwell, J. Gutteridge, Free Radicals in Biology and Medicine, 3rd ed., Oxford Science Publications University Press, Oxford, 2003.

[3] J.D. Lambeth, Free Radic. Biol. Med. 43 (2007) 332-347.

[4] J.M.C. Gutteridge, Free Radic. Res. Commun. 19 (1993) 141-158.

[5] B. Halliwell, Nutr. Rev. 52 (1994) 253-263.

[6] P-.G. Pietta, J. Nat. Prod. 63 (2000) 1035-1042.

[7] D. Huang, B. Ou, R.L. Prior, J. Agric. Food Chem. 53 (2005) 1841-1856.

[8] G. Cao, R.L. Prior, Clin. Chem. 44 (1998) 1309-1315.

[9] E.N. Frankel, A.S. Meyer, J. Sci. Food Agric. 80 (2000) 1925-1941.

[10] C. Santos-Buelga, G. Williamson, Methods in Polyphenol Analysis, Royal Society of Chemistry, Cambridge, 2003.

[11] V. Roginsky, E.A. Lissi, Food Chem. 92 (2005) 235-254.

[12] R.L. Prior, X. Wu, K. Schaich, J. Agric. Food Chem. 53 (2005) 4290-4302.

[13] N. Hermans, P. Cos, L. Maes, T. De Bruyne, D. Vanden Berghe, A.J. Vlietinck, L. Pieters, Curr. Med. Chem. 14 (2007) 417-430.

[14] Antioxidant measurement and applications, ACS Symposium Series 956, in: F. Shahidi, C.-T. Ho (Eds.), Oxford University Press (2007).

[15] Y. O’Dowd, F. Driss, P. My-Chan Dang, C. Elbim, M.A. GougerotPocidalo, C. Pasquier, J. El-Benna, Biochem. Pharmacol. 68 (2004) 2003-2008.

[16] N. Saint-Cricq de Gaulejac, C. Provost, N. Vivas, J. Agric. Food Chem. 47 (1999) 425-431.

[17] D.T. Sawyer, Oxygen Chemistry, Oxford University Press, Oxford, 1991, p. 27.

[18] D. Vasudevan, W. Wendt, J. Electroanal. Chem. 192 (1995) 69-74.

[19] G. Feroci, A. Fini, Inorg. Chim. Acta 360 (2007) 1023-1031.

[20] R.D. Webster, A.M. Bond, J. Chem. Soc. Perkin Trans. 2 (1997) 1075-1080.

[21] T. Araki, H. Kitaoka, Chem. Pharm. Bull. 49 (2001) 541-545.

[22] M.E. Ortiz, L.J. Nunez-Vergara, J.A. Squella, J. Electroanal. Chem. 519 (2002) 46-52.

[23] S. Bollo, J. Jara-Ulloa, S. Finger, L.J. Nunez-Vergara, J.A. Squella, J. Electroanal. Chem. 577 (2005) 235-242.

[24] M.L. Abasq, J.L. Burgot, M.O. Christen, A. Darchen, S. Dervout, Proceedings of the 11th International Biennial Meeting of the Society for Free Radical Research, Paris, France, 2002, pp. 575-578.

[25] A.J. Blasco, A.G. Crevillen, M.C. Gonzales, A. Escarpa, Electroanalysis 19 (2007) 2275-2286.

[26] C. Dapremont-Avignon, P. Calas, A. Commeyras, C. Amatore, J. Fluorine Chem. 51 (1991) 357-379.

[27] D.H. Evans, K.M. O'Connell, R.A. Petersen, M.J. Kelly, J. Chem. Educ. 60 (1983) 290-293.

[28] M.B. Arnao, Trends Food Sci. Technol. 11 (2000) 419-421.

[29] S.V. Jovanovic, S. Steenken, M. Tosic, B. Marjanovic, M.G. Simic, J. Am. Chem. Soc. 116 (1994) 4846-5485.

[30] J.P. Hu, M. Calomme, A. Lasure, T. De Bruyne, L. Pieters, A. Vlietinck, D.A. Vanden Berghe, Biol. Trace Elem. Res. 47 (1995) 327-331.

[31] N. Cotelle, P. Hapiot, J. Pinson, C. Rolando, H. Vézin, J. Phys. Chem. B 109 (2005) 23720-23729.

[32] C.P. Andrieux, P. Hapiot, J.M. Savéant, J. Am. Chem. Soc. 109 (1987) 3768-3775.

[33] C.M. Collins, C. Sotiriou-Leventis, M.T. Canalas, N. Leventis, Electrochim. Acta 45 (2000) 2049-2059.

[34] C.A. Rice-Evans, N.J. Miller, G. Paganga, Free Radic. Biol. Med. 20 (1996) 933-956.

[35] D. Rosch, M. Bergmann, D. Knorr, L.W. Kroh, J. Agric. Food Chem. 51 (2003) 4233-4239.

[36] O. Firuzi, A. Lacanna, R. Petrucci, G. Marrosu, L. Saso, Biochim. Biophys. Acta 1721 (2005) 174-184.

[37] D. Villaňo, M.S. Fernandez-Pachon, A.N. Troncoso, M.C. Garcia-Parrilla, Anal. Chim. Acta 538 (2005) 391-398.

[38] S.A.B.E. Van Acker, D.-J. van den Berg, M.N.J.L. Tromp, D.H. Griffionen, W.P. van Bennekom, W.J.F. van der Vijgh, A. Bast, Free Radic. Biol. Med. 20 (1996) 331-342. 